\title{
Ammoniacal deutochloride of titanium
}

\section{Rose}

To cite this article: M. Rose (1830) Ammoniacal deutochloride of titanium, Philosophical Magazine Series 2, 8:47, 388-388, DOI: $10.1080 / 14786443008675485$

To link to this article: http://dx.doi.org/10.1080/14786443008675485

曲 Published online: 10 Jul 2009.

Submit your article to this journal $2 \pi$

III Article views: 1

Q View related articles $\sqsubset$ 
Our readers will remember that Faraday and Mitscherlich have de. scribed another compound, consisting of

2 atoms phosphorus +1 atom sulphur.

Brewster's Journal.-Ann. de Chim. xliii. p. 25.

PREPARATION OF PHOSPHORUS.

Wöhler recommends, as likely to give phosphorus at a very cheap rate, to distil by a strong heat ivory-black, with half its weight of fine sand and charcoal powder. A silicate of lime is formed, and the carbonic oxide and phosphorus come over.-Brewster's Journal.-Poggendorf.-Ann. de Phys. xvii. p. 178.

AMMONIACAL DEUTOCHLORIDE OF TITANIUM. BY M. ROSE.

When dry ammoniacal gas is passed over deutochloride of titanium, there is strong action, accompanied with the evolution of heat, and a brownish red powder is formed. This powder combines with the portion of deutochloricle which remains unacted upon, and is not further attacked by the ammoniacal gas; the mixture is to be well shaken, and when the ammonia, as detected by the smell, is in excess, the operation is finished.

When in contact with the air the compound becomes white; it liquefies in moist air. It is not perfectly soluble in water. According to analysis it consists of 84.71 of deutochloride of titanium and 15.29 of ammonia.-Hensman's Repertoire, vol. iii. p. 304.

ON AN ALIEGED ERROR IN THE CALCULATIONS OF THE LATE FCLIPSE OF THE MOON.

To the Editors of the Philosophical Magazine and Annals.

Gentlemen, Bristol, Small-Street Court, Sept. 28, 1830.

I take the liberty of troubling you with the following letter, which is a copy (or nearly so) of one sent to the Literary Gazette, which the editor declined inserting. I submit it to you for insertion or rejection, as you may think fit.

The occasion of it was briefly as follows. The late eclipse of the "labouring moon" had given birth to a couple of articles in the Literary Gazette, one by C. H. Adams of Edmonton; the other by J.T. B. of Deptford, both complaining of great inaccuracy in the calculations of our almanacs in relation to that eclipse, and re. flecting discredit on the science of astronomy itself. The latter gentleman says (Literary Gazette, 11 th of September), after alluding to the unfavourable state of the weather on the evening of the eclipse, "The only observation made was at $10^{\mathrm{h}} 15^{\mathrm{m}}$, at which time a portion of the western limb of the moon was distinctly seen to be illuminated, $-27 \cdot 4 \mathrm{~m}$ after the time predicted for the beginning of total darkness." .... "It is, however, due to the Nautical Almanac, and other British astronomical works of a similar nature, to state that the times of the phænomena of this eclipse, as given by them, agree nearly with those in the Connaissance des Tems and Encke's Berlin Ephemeris, both of which are deservedly held in the highest estimation." He then quotes from the computations of the 